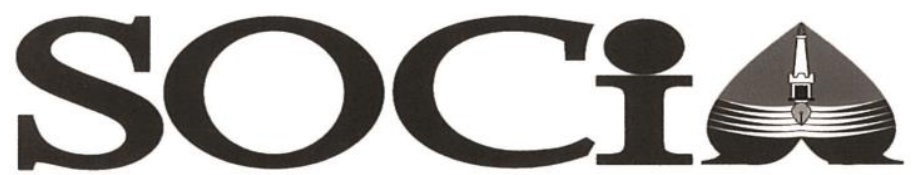

\title{
Pengaruh Model Nested dan Webbed Terhadap Hasil Belajar IPS Terpadu SMP
}

\author{
SEPTI KUNTARI, MUHSINATUN SIASAH MASRURI \\ Program Pascasarjana, Universitas Negeri Yogyakarta \\ princezz_ice@ymail.com,muhsinsiasah@gmail.com
}

\begin{abstract}
Abstrak
Penelitian ini bertujuan untuk mengetahui perbedaan hasil belajar IPS siswa yang menggunakan model pembelajaran nested dan model pembelajaran webbed. Penelitian eksperimen menggunakan desain Randomized Posttest-Only Control Group Design. Teknik pengambilan sampel menggunakan multistage random sampling. Validasi instrumen dilakukan dengan validasi logis (expert judgement) dan validasi empiris melalui ujicoba untuk mengukur daya pembeda soal dengan taraf signifikansi 0,05. Hasil penelitian menunjukkan bahwa: rata-rata hasil belajar dengan menggunakan model nested dan dengan menggunakan model webbed dengan nilai t sebesar $0,314>0,05$, artinya tidak ada perbedaan yang signifikan. Dengan demikian hasil belajar dengan model nested maupun model webbed tidak berbeda secara signifikan.
\end{abstract}

Kata Kunci : Pengaruh, Model Nested, Model Webbed

\begin{abstract}
This study aims to investigate the difference in the learning outcomes of Social Studies between the students learning through the nested learning model and those learning through the webbed learning model. This was an experimental study employing the randomized posttest-only control group design. The sample was selected by means of the multistage random sampling technique. The instrument validation was conducted through logical validation (expert judgment) and empirical validation by a tryout to assess the discrimination index of the items at a significance level of 0.05 . The results of the study showed that the average learning outcomes through the nested and webbed models were indicated by a $t$ value of $0.314>0.05$, showing that there was no significant difference. Therefore, the learning outcomes through the nested model and those through the webbed model did not differ significantly.

Keywords: effects, nested model, webbed model
\end{abstract}




\section{PENDAHULUAN}

Pendidikan merupakan pengalaman belajar yang berlangsung sepanjang hidup (Mudyahardjo, 2009:3). Proses pendidikan sangat memerlukan model-model pembelajaran yang sesuai agar kegiatan pembelajaran dapat berjalan dan berhasil dengan baik. Tantangan pendidikan di Indonesia saat ini sangat besar. Kualitas pendidikan, baik dalam aspek kognitif, afektif, maupun psikomotorik. Dengan adanya kemajuan teknologi informasi yang begitu canggih, dunia ini terasa menjadi kecil sehingga peristiwa yang terjadi di suatu tempat tertentu dengan cepat diketahui oleh masyarakat di seluruh dunia. Tantangan pendidikan yang semakin kompleks, menuntut guru-guru agar mempunyai kompetensi yang komprehensif untuk menjalankan tugasnya mendidik dan mencerdaskan generasi muda, berdedikasi tinggi, demokratis, dan bersikap professional.

Menurut Peraturan Pemerintah No 74 tahun 2008:

Pasal 1 Ayat 1:

Guru adalah pendidik profesional dengan tugas utama mendidik, mengajar, membimbing, mengarahkan, melatih, menilai, dan mengevaluasi peserta didik pada pendidikan anak usia dini,dan jalur pendidikan formal, pendidikan dasar, dan pendidikan menengah.
Pasal 2 Ayat 1:

Guru wajib memiliki kualifikasi akademik, kompetensi, sertifikat pendidik, sehat jasmani dan rohani, serta memiliki kemampuan untuk mewujudkan tujuan pendidikan nasional.

Sebagai pendidik profesional yang memiliki tugas mendidik, mengajar, membimbing, mengarahkan, melatih, menilai, dan mengevaluasi peserta didik, seorang guru menjadi salah satu faktor kunci keberhasilan pendidikan. proses yang guru lakukan dalam pendidikan tidak sebatas pada fasilitator pembelajaran namun menyeluruh pada proses pendidikan yang dialami oleh peserta didik. Dalam hal ini guru juga tidak sekedar fokus untuk mengembangkan dan menyampaikan kajian keilmuan namun juga mentransfer nilai-nilai kehidupan bagi peserta didik. Oleh karena itu tugas guru profesional berkaitan erat dengan proses perkembangan peserta didik berhadapan dengan perkembangan keilmuan dan perkembangan lingkungan sosial.

Guru memegang peranan penting dalam sistem dan proses pendidikan, Para siswa tidak mungkin belajar sendiri tanpa bimbingan guru yang mampu mengemban tugasnya dengan baik. Pada hakikatnya para siswa hanya mungkin belajar dengan baik jika guru telah mempersiapkan lingkungan yang positif bagi mereka untuk 
belajar (Hamalik, 2005: 43). Guru tidak hanya sekedar bertugas untuk dapat menjalankan tugas mengajar namun memberikan dorongan kepada siswa untuk dapat mengembangkan keilmuaannya secara mandiri.

Guru IPS dituntut untuk mempunyai kemampuan yang baik dalam melaksanakan kegiatan pembelajaran agar tercapai hasil belajar siswa yang baik. Untuk mengetahui sejauh mana siswa telah berhasil menguasai kompetensi yang dipelajari diperlukan kompetensi guru untuk menilai secara otentik.

Menurut Arikunto (2006:6-8) guru maupun pendidik lainnya perlu mengadakan penilaian terhadap hasil belajar siswa karena dalam dunia pendidikan, khususnya dunia persekolahan penilaian hasil belajar mempunyai makna yang penting, baik bagi siswa, guru maupun sekolah.

Pengetahuan sosial melekat dalam diri setiap siswa, pengetahuan sosial diperoleh dari kehidupan sehari-hari dan ada pada setiap siswa. Hal ini masih belum cukup mengingat pentingnya kehidupan dalam bermasyarakat dengan berbagai macam permasalahan yang berkembang. Pengetahuan sosial yang diperoleh dalam pendidikan formal yaitu pendidikan IPS mempunyai tujuan agar siswa menjadi warga negara yang baik, mempunyai pengetahuan, keterampilan serta kepedulian sosial yang tinggi. Objek kajian IPS yang cukup luas menuntut guru dan siswa untuk dapat kreatif fan inovatif dalam menciptakan suasana pembelajaran yang menyenangkan. Hasil belajar siswa meliputi berbagai kemampuan yang dapat diukur baik secara kuantitatif maupun pengalaman yang menjadi bekal bagi siswa untuk dapat mengimplementasikan berbagai ilmu yang dipelajari.

Salah satu kunci keberhasilan pembelajaran IPS adalah adanya perubahan perilaku sosial siswa kearah yang positif atau lebih baik. Namun, untuk mencapainya sangat tergantung dari kemampuan guru dalam memberikan pembelajaran IPS di kelas. Guru IPS dapat menggunakan berbagai media pembelajaran yang relevan untuk menunjang kegiatan belajar mengajar di kelas, selain itu guru IPS juga dapat menggunakan metode-metode pembelajaran yang sesuai dan dapat menarik siswa agar lebih memahami materi yang diberikan oleh guru.

Dalam penilaian hasil belajar, guru IPS harus objektif memberi nilai sesuai dengan tingkat penguasaan kompetensi yang diharapkan. Siswa yang telah berhasil mencapai Kriteria Ketuntasan Minimal (KKM) berhak melanjutkan pelajaran kejenjang berikutnya. Sementara 
untuk siswa yang belum menuntaskan menguasai semua bidang studi IPS. kompetensi belajarnya dengan baik, Sementara masih banyak guru yang dilakukan pembelajaran ulang (program merasa kesulitan untuk mempelajari remedial) sampai siswa dapat mencapai bidang studi IPS yang lain. Hal ini standar kriteria ketuntasan minimal membuat pembelajaran IPS yang (KKM).

dilaksanakan dilapangan belum

Penilaian hasil belajar hendaknya sepenuhnya terpadu, guru-guru IPS menerapkan sistem penilaian mengajar sesuai dengan bidang studi komprehensif yang mencakup tiga aspek mereka masing-masing. yaitu aspek kognitif, psikomotor, dan afektif. Pada umumnya, hasil belajar dapat dikelompokkan menjadi tiga aspek yaitu kognitif, psikomotor, dan afektif. Apapun jenis mata pelajarannya selalu mengandung tiga aspek tersebut namun memiliki penekanan yang berbeda. Mata pelajaran praktik lebih menekankan pada ranah psikomotor, sedangkan mata pelajaran konsep lebih menekankan pada ranah kognitif. Namun kedua jenis pembelajaran tersebut mengandung ranah afektif.

Untuk mengantisipasi hal tersebut, pemerintah melaksanakan pelatihan kepada guru-guru tentang pembelajaran IPS terpadu dari tingkat nasional hingga tingkat daerah. Namun kenyataan di lapangan menunjukkan bahwa sebagian besar guru-guru belum mau menerapkan pembelajaran IPS secara terpadu. Sebagian guru beralasan bahwa pembelajaran IPS yang dilaksanakan secara terpadu membuat guru harus

Pentingnya pembelajaran terpadu dilaksanakan karena sesuai dengan kehidupan di masyarakat yang saling tergantung dan terikat satu dengan yang lainnya. Melalui pembelajaran terpadu, siswa diharapkan dapat membangun budaya berpikir positif yang selalu mengedepankan pemecahan masalah dari berbagai aspek

Ada sepuluh model rancangan terpadu (integrated curriculum) dari Fogarty (1991:v-vi) yaitu fragmented model, connected model, nested model, sequenced model, shared model, webbed model, threaded model, integrated model, immersed model, dan networked model.

Berdasarkan prasurvei yang dilakukan di SMPN 2 dan SMPN 3 Depok, ternyata guru IPS belum sepenuhnya menerapkan pembelajaran IPS secara terpadu. Hal ini dilihat dari para guru IPS yang belum menerapkan salah satu dari model pembelajaran terpadu. 
Penelitian ini dilakukan untuk menggunakan kelas kontrol, melainkan mengetahui hasil belajar IPS terpadu, menggunakan dua kelompok eksperimen. menggunakan model nested dan model Proses eksperimen semu dengan webbed di SMPN 2 Depok dan SMPN 3 melakukan pengamatan pada dua Depok.

Pembelajaran IPS di sekolah yang kelompok pembelajaran. Dalam penelitian ini yang dieksperimenkan adalah dilaksanakan secara terpisah, artinya tidak secara terpadu sangat dikhawatirkan akan berdampak pada hasil belajar siswa yang kurang dari kriteria ketuntasan minimal (KKM). Hal ini berarti bahwa pembelajaran IPS terpadu dengan model nested dan model webbed.

Tabel 1.Desain Penelitian Randomized Posttest-Only Control Group Design

\begin{tabular}{ccc}
\hline $\begin{array}{c}\text { Kelompok } \\
\text { (Group) }\end{array}$ & Perlakuan (X) & Pascatest Y) \\
\hline Acak A (KE) & Webbed & 0 \\
\hline Acak B (KE) & Nested & 0
\end{tabular}

secara terpadu agar siswa dapat mencapai kompetensi yang diharapkan. Terdapat berbagai cara yang sebenarnya dapat dilakukan oleh guru untuk berkreativitas terhadap proses pembelajaran sehingga guru mampu memperoleh pengalaman pembelajaran. Selain itu proses pembelajaran diupayakan untuk dapat mengembangkan minat dan prestasi belajar siswa.

Sesuai dengan latar belakang di atas, penelitian ini dilakukan untuk mengetahui perbedaan hasil belajar IPS terpadu dengan menggunakan model nested dan model webbed di SMPN 2 Depok dan SMPN 3 Depok.

\section{METODE}

Desain penelitian yang digunakan adalah Randomized Posttest-Only Comparison Group Design. Desain Penelitian ini tidak

(Sukmadinata, 2009: 206).

Penelitian ini dilaksanakan pada dua SMPN yaitu SMPN 2 depok, SMPN 3 depok. Dilaksanakan pada tahun pelajaran 2013/2014, yakni pada bulan juliseptember 2013. Populasi dalam penelitian ini adalah SMPN di Kecamatan Depok yang berjumlah 5 sekolah. Dari 5 populasi diambil dua sampel yang dipilih menggunakan random sampling. Sampel ditentukan dengan teknik multistage random sampling atau sampel bertahap. Variabel dalam penelitian ini terdiri atas variabel bebas dan variabel terikat

Teknik pengumpulan data menggunakan tes dan non tes. Untuk instrumen pengumpulan data menggunakan instrumen tes hasil belajar. Validasi instrumen dilakukan dengan validasi logis (expert judgement) dan 
validasi empiris melalui ujicoba untuk mengukur daya pembeda soal dengan taraf signifikansi 0,05. Uji reliabilitas instrumen dilakukan setelah uji validitas instrumen, sehingga hanya butir yang valid saja yang diuji.

Sesuai dengan rancangan penelitian yang menggunakan desain eksperimen, maka setelah melakukan beberapa kali eksperimen lalu dilakukan tes. Hasil tes merupakan data hasil belajar IPS terpadu yang digunakan untuk menguji hipotesis penelitian. Uji hipotesis dilakukan pada satu uji, karena hipotesisnya hanya ada satu. Sebelum melakukan uji hipotesis, terlebih dahulu dilakukan uji persyaratan analisis yaitu Uji normalitas dan Uji homogenitas.

Selanjutnya dilakukan deskripsi data dengan analisis deskriptif terhadap variabel penelitian. Teknik analisa data yang digunakan untuk menguji hipotesis adalah dengan menggunakan uji-t dengan SPSS 13,00.

\section{HASIL DAN PEMBAHASAN}

Dalam penelitian ini terdapat data posttest hasil belajar, pada kelompok eksperimen 1 maupun pada kelompok eksperimen 2. Data hasil belajar (posttest) baik pada kelompok eksperimen 1 maupun kelompok eksperimen 2 diperoleh dari pelaksanaan posttest yang diberikan setelah kegiatan pembelajaran selesai dilaksanakan. Kegiatan posttest dilaksanakan pada dua kelompok yaitu kelompok eksperimen 1 dan kelompok eksperimen 2. Pengambilan data posttest mempunyai tujuan yaitu untuk mengetahui pencapaian hasil belajar IPS di tiap-tiap kelompok. Dengan mengetahui hasil belajar IPS pada kelompok eksperimen 1 dengan menggunakan model webbed dan pada kelompok eksperimen 2 dengan menggunakan model nested, maka akan diketahui model manakah yang paling efektif dalam pencapaian hasil belajar IPS Terpadu. Model yang paling efektif akan menunjukkan bahwa salah satu model mempunyai keunggulan dibandingkan dengan model pembelajaran yang lainnya. Model pembelajaran yang paling efektif akan menetukan hasil belajar siswa yang lebih baik lagi.

Deskripsi data pottest dari 30 siswa pada kelompok eksperimen 1 yang mengikuti pembelajaran dengan menggunakan model webbed di SMPN 2 Depok, dapat disajikan dalam bentuk tabel berikut ini. 
Tabel 2. Data Tes Hasil Belajar IPS Kelompok Eksperimen 1 (Model Webbed)

\begin{tabular}{ll}
\hline $\mathrm{N} \quad$ Valid & 30 \\
\hline \multicolumn{1}{c}{ Missing } & 0 \\
\hline Mean & 74,0667 \\
\hline Median & 76,0000 \\
\hline Std. Deviation & 7,62000 \\
\hline Variance & 58,064 \\
\hline Minimum & 62,00 \\
\hline Maximum & 94,00
\end{tabular}

Distribusi frekuensi dapat dilihat dalam bentuk histogram berikut,

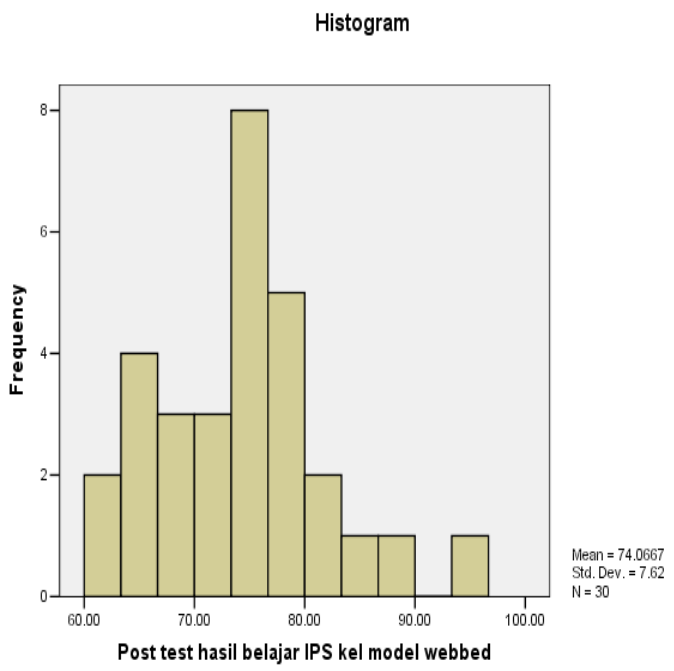

Gambar 1 Histogram Hasil Posttest Siswa Yang Mengikuti Pembelajaran IPS Dengan Model Webbed ( Kelompok Eksperimen 1)

Berdasarkan data posttest dari kelompok eksperimen 1 yang menggunakan model webbed, dapat diketahui bahwa rerata (mean) 74,06, median 76,00 , standar deviasi 7,62, variansi 58,06, nilai minimal 62 dan nilai maksimal 94. Hasil rerata ini nantinya akan dibandingkan dengan hasil dari model pembelajaran nested. Untuk mengetahui manakah yang paling efektif model pembelajaran yang digunakan untuk mencapai hasil belajar IPS yang komprehensif.

Deskripsi data posttest hasil belajar IPS terpadu dari 32 siswa pada kelompok eksperimen 2 dengan menggunakan model pembelajaran nested di SMPN 3 Depok, dapat disajikan dalam bentuk tabel sebagai berikut:

Tabel 3. Data Tes Hasil Belajar IPS Kelompok Eksperimen 2 (Model Nested)

\begin{tabular}{ll}
\hline $\mathrm{N} \quad$ Valid & 32 \\
\hline \multicolumn{1}{c}{ Missing } & 0 \\
\hline Mean & 82,5000 \\
\hline Median & 83,0000 \\
\hline Std. Deviation & 8,84271 \\
\hline Variance & 78,194 \\
\hline Minimum & 62,00 \\
\hline Maximum & 98,00 \\
\hline
\end{tabular}

Distribusi frekuensi dapat dilihat dalam bentuk histogram berikut,

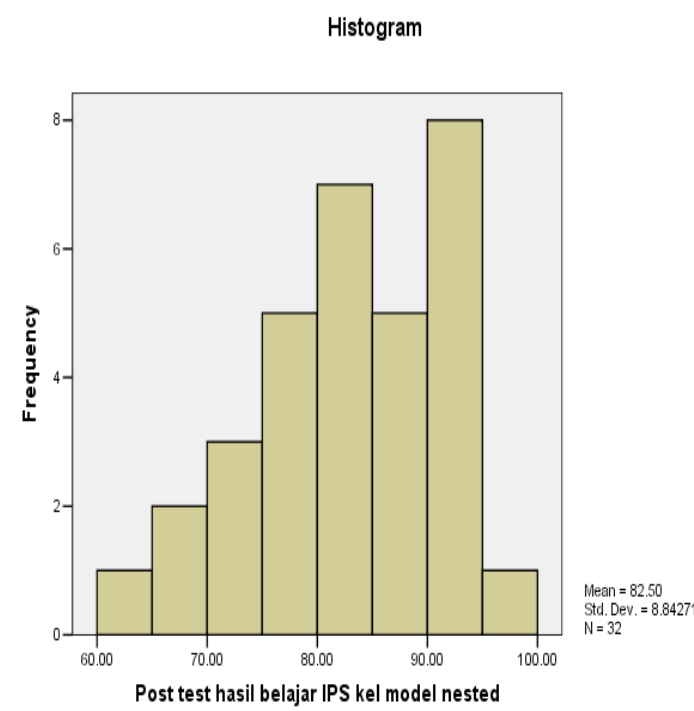

Gambar 2 Histogram Hasil Posttest Siswa Yang Mengikuti Pembelajaran IPS Dengan Model Nested ( Kelompok Eksperimen 2) 
Berdasarkan data posttest dari Tabel 4. Hasil Uji Normalitas Data Post Test kelompok eksperimen 2 yang menggunakan model Nested, dapat diketahui bahwa rerata (mean) 82,50, median 83,00, standar deviasi 8,84, variansi 78,19, nilai minimal 62 dan nilai maksimal 98.

Data yang dianalisis adalah data yang diperoleh setelah perlakuan, dengan tujuan untuk mengetahui perbedaan hasil belajar yang menggunakan dua model pembelajaran, yaitu model pembelajaran webbed dan model pembelajaran nested. Uji Setelah Perlakuan (Posttest)

1. Uji Normalitas

Uji normalitas yang digunakan pada penelitian ini yaitu uji Kolmogorofsmirnov dengan bantuan SPSS 13,00 for windows. Uji normalitas digunakan untuk mengetahui apakah data berdistribusi normal atau tidak. Jika data berdistribusi normal, maka dapat dilakukan uji statistic lanjut, yaitu untuk menguji hipotesis penelitian. Hasil uji normalitas data setelah perlakuan disajikan pada tabel dibawah ini.

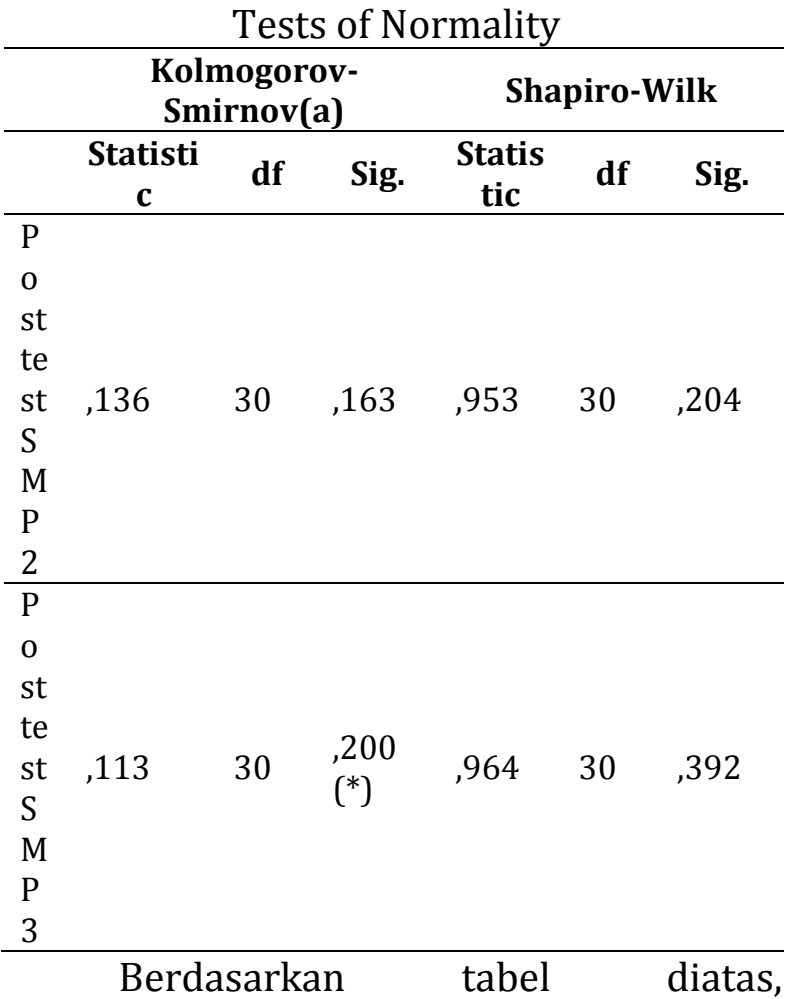

menunjukkan bahwa semua variabel terikat pada kedua kelompok eksperimen memiliki nilai signifikansi lebih dari 0,05. Oleh karena itu, hipotesis $\left(\mathrm{H}_{0}\right)$ yang menyatakan "data berdistribusi normal" diterima sehingga data tersebut berdistribusi normal.

Uji normalitas data dilakukan terhadap data skor hasil belajar untuk masing-masing subjek perlakuan sesuai dengan rancangan penelitian yang menggunakan desain eksperimen. Dalam penelitian ini menggunakan tiga kelompok, yakni; dua kelas eksperimen yang diberikan perlakuan dengan menggunakan model nested dan model webbed. 
Tujuan melakukan pengujian eksperimen memiliki varian yang normalitas data adalah untuk mengetahui homogen. Hal ini menunjukkan bahwa apakah varians atau data pada masing- antara model nested dan model webbed masing kelompok berdistribusi normal. tidak berbeda keefektifannya.

Jika data berdistribusi normal, maka pengujian hipotesis dapat menggunakan uji-t.

\section{Uji Homogenitas}

Tujuan melakukan uji homogenitas adalah untuk mengetahui apakah data penelitian pada masing-masing kelompok eksperimen setelah diberikan perlakuan memiliki hasil yang tidak homogen, artinya apakah ada perbedaan hasil belajar antara model nested dan model webbed.

Tabel 5. Uji Homogenitas Data Post test

\begin{tabular}{lllll}
\multicolumn{5}{c}{ Test of Homogeneity of Variance } \\
\hline & $\begin{array}{l}\text { Levene } \\
\text { statistic }\end{array}$ & df1 & df2 & Sig. \\
\hline $\begin{array}{l}\text { Based on } \\
\text { mean }\end{array}$ & 1,034 & 1 & 58 &, 314 \\
\hline $\begin{array}{l}\text { Based on } \\
\text { median }\end{array}$ &, 981 & 1 & 58 &, 326 \\
\hline $\begin{array}{l}\text { Based on } \\
\text { median and } \\
\text { with } \\
\text { adjusted df }\end{array}$ & 981 & 1 & 58,000 &, 326 \\
\hline $\begin{array}{l}\text { Based on } \\
\text { trimmed } \\
\text { mean }\end{array}$ &, 912 & 1 & 58 &, 343 \\
\hline
\end{tabular}

Dari tabel tersebut menunjukkan bahwa nilai signifikansi yang diperoleh lebih dari 0,05. Hal ini menunjukkan bahwa hipotesis (H0) yang menyatakan bahwa "varians data dari ketiga kelompok adalah homogen" diterima. Oleh karena itu, variabel dependen kedua kelompok
3. Uji Hipotesis

Pengujian hipotesis dilakukan dengan statistik uji-t, data yang di uji yaitu data posttest pada kelompo eksperimen 1 (model webbed) dan kelompok eksperimen 2 (model nested). Hipotesis yang di uji yaitu ada perbedaan yang signifikan antara model webbed dan model nested. Uji Hipotesis dilakukan setelah selesai diberikan perlakuan (treatment). Dengan kriteria penerimaan dan penolakan hipotesis sebagai berikut:

1. Jika probabilitas (p) > 0,05 maka hipotesis nihil (H0) diterima, artinya tidak ada perbedaan yang signifikan antara kedua kelompok.

2. Jika probabilitas (p) $<0,05$ maka hipotesis nihil (HO) ditolak, artinya ada perbedaan yang signifikan antara kedua kelompok.

Uji-t Pada Data Post Test (Setelah treatment)

Berikut ini merupakan hasil perhitungan post test dengan uji-t yang menggunakan SPSS 13,00. 
Tabel 6. Hasil Perhitungan Post test dengan

$$
\text { uji-t }
$$

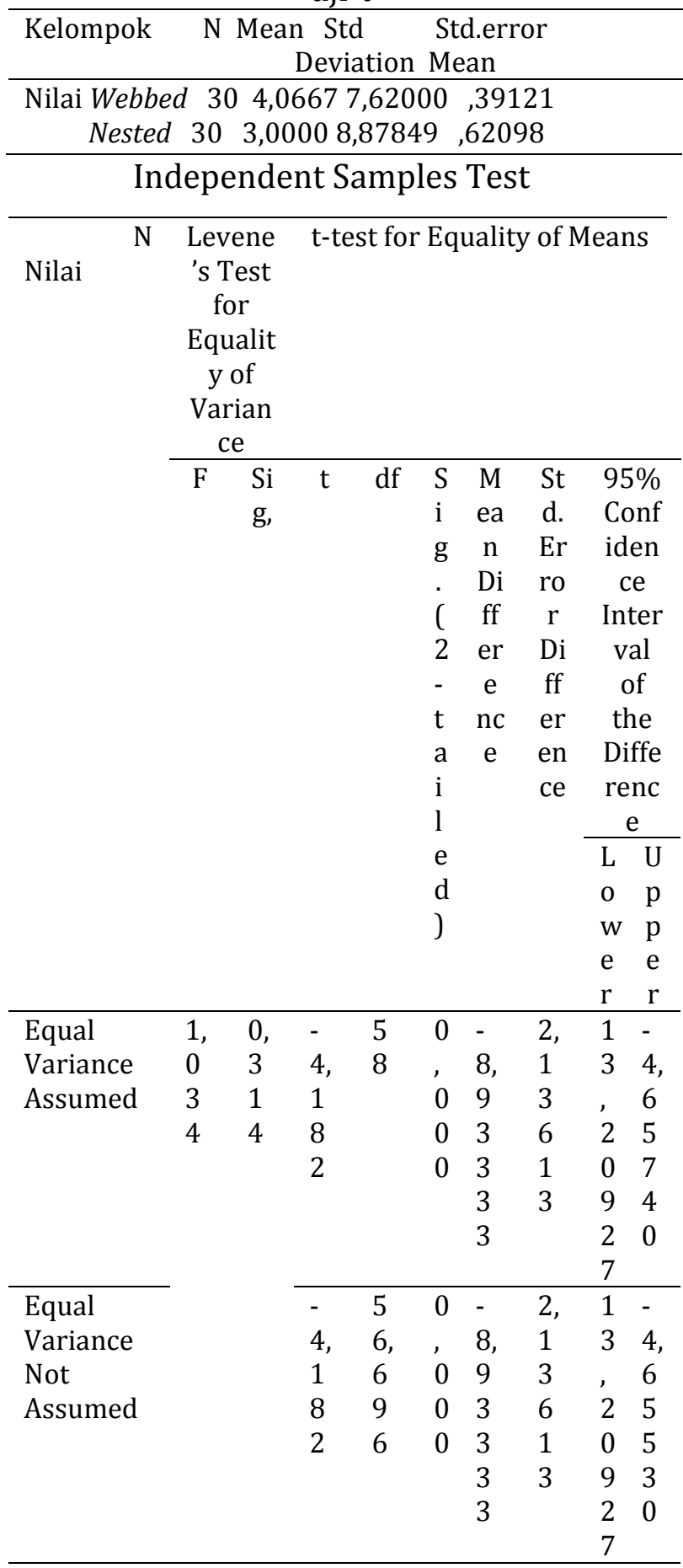

Hasil uji-t menampilkan jumlah subjek pada masing-masing kelompok yaitu 30, mean kelompok eksperimen 1 (model webbed) adalah 74,06 dengan standar deviasi 7,62 serta standar error of mean 1,39 .Sedangkan mean kelompok eksperimen 2 (model nested) adalah 83,00 dengan standar deviasi 8,87 serta standar error of mean 1,62. Berdasarkan tabel diatas, diketahui bahwa $\mathrm{F}=1,034$, signifikansi $=0,314$ dan $\mathrm{t}=-4,182$. Dari hasil tersebut disimpulkan bahwa dengan taraf signifikansi 0,05 menunjukkan bahwa $0,314>0,05$ artinya tidak ada perbedaan yang signifikan antara model webbed dan model nested, keduanya samasama efektif, berarti $\mathrm{H}_{0}$ diterima.

Kesimpulannya bahwa kedua kelompok eksperimen, sebelum diberikan perlakuan (treatment) mempunyai kemampuan awal yang tidak berbeda jauh artinya kedua kelompok setara. Setelah kegiatan pembelajaran selesai, pada kedua kelompok eksperimen diberikan posttest, bertujuan untuk mengetahui pengaruh kedua model pembelajaran tersebut. Hasil posttest menunjukkan bahwa antara model webbed dan model nested samasama efektif dilihat dari perolehan signifikansi yang menunnjukkan bahwa tidak ada perbedaan yang signifikan diantara kedua model pembelajaran tersebut.

Dari hasil uji-t menggunakan SPSS 13,00 terhadap data hasil pre test pada kelompok eksperimen 1 (model webbed) dan kelompok eksperimen 2 (model nested) diperoleh $\mathrm{F}=0,156, \mathrm{p}=0,694$ dan $t=0,196$. Dengan taraf signifikansi 0,05 
berarti $\mathrm{H}_{0}$ diterima karena 0,694 > 0,05 yang artinya tidak ada perbedaan yang signifikan antara kedua kelompok.

Uji Hipotesis yang kedua dengan menggunakan uji-t diperoleh $\mathrm{F}=1,034, \mathrm{p}$ $=0,314$ dan $t=-4,182$. Dengan taraf signifikansi 0,05 berati H0 diterima karena $0,314>0,05$ yang artinya tidak ada perbedaan yang signifikan antara kedua kelompok. Kesimpulannya bahwa model pembelajaran webbed dan model pembelajaran nested tidak berbeda keefektifannya.

Berdasarkan hasil eksperimen menunjukkan bahwa tidak ada perbedaan yang signifikan antara hasil belajar dengan menggunakan model nested dan model webbed. Hal ini dibuktikan dengan diperoleh signifikansi $0,314>0,05$. Terjadinya hasil belajar yang hampir sama dengan menggunakan model webbed dan model nested dikarenakan masing-masing model pembelajaran mempunyai keunggulan dan kelemahan masingmasing. Keterampilan guru atau kreativitas guru juga sangat menentukan keberhasilan penggunaan model pembelajaran terpadu khususnya.

Model pembelajaran webbed mempunyai keunggulan yaitu dengan cara menentukan tema tertentu yang ditentukan oleh guru bersama dengan siswa. Penentuan tema harus sesuai dengan minat belajar siswa, yaitu tema yang disukai oleh siswa agar siswa lebih memahami materi pembelajaran. Akan tetapi, untuk menetukan tema sangatlah tidak mudah karena butuh tema yang sesuai dengan materi yang akan dibahas. Guru juga harus dituntut lebih kreatif untuk menetukan tema yang disukai oleh siswa. Biasanya, lebih banyak digunakan oleh guru yang belum berpengalaman. Dalam pembelajaran model webbed guru lebih memusatkan perhatian kepada kegiatan daripada pengembangan konsep. Inilah yang menjadi penyebab kenapa rerata hasil belajar yang menggunakan model webbed lebih rendah daripada menggunakan model nested.

Sementara itu, model nested memadukan beberapa keterampilan dalam suatu pembelajaran di dalam satu unit mata pelajaran. Keterampilanketerampilan belajar itu meliputi keterampilan berpikir (thinking skill), keterampilan sosial (social skill) dan keterampilan mengorganisir (organizing skill). Dengan memfokuskan pada isi pelajaran, strategi berpikir, keterampilan sosial, dan keterampilan mengorganisir, satu pelajaran dapat mencakup banyak hal. Meskipun, model nested mempunyai kelemahan yaitu terletak pada guru ketika tanpa perencanaan yang matang memadukan beberapa keterampilan yang 
menjadi target dalam suatu pembelajaran, akan berdampak pada siswa, dimana prioritas pelajaran akan menjadi kabur.

Tidak adanya perbedaan hasil belajar yang signifikan antara hasil belajar menggunakan model webbed dan model nested menunjukkan bahwa kedua model pembelajaran terpadu tidak berbeda keefektifannya. Model webbed dan model nested merupakan model pembelajaran terpadu yang mempunyai keunggulan berbeda, akan tetapi dapat menghasilkan hasil belajar IPS yang tidak berbeda jauh.

Dapat disimpulkan bahwa, tidak terjadinya perbedaan hasil belajar IPS yang menggunakan model webbed dan model nested karena keduanya tidak berbeda keefektifannya. Hal ini juga sangat tergantung dari kreativitas guru mata pelajaran IPS yang dituntut kreatif untuk mengembangkan model pembelajaran terpadu dalam proses belajar mengajar di kelas.

Berdasarkan permasalahan dilapangan menunjukkan bahwa guru masih menggunakan metode pembelajaran yang kurang bervariasi. belum menerapkan model-model pembelajaran terpadu. Hal ini dilihat dari kegiatan pembelajaran yang belum menunjukkan keterpaduan, guru belum menggunakan suatu tema tertentu untuk membuat pembelajaran lebih menarik dan lebih terpadu. Hal ini dikarenakan masih kurangnya pemahaman guru mengenai model-model pembelajaran terpadu.

Dari berbagai masalah yang timbul membuat peneliti menerapkan model pembelajaran terpadu di dalam kegiatan pembelajaran. Model yang diterapkan yaitu model nested dan model webbed. Antara model nested dan model webbed masing-masing mempunyai keunggulan dan kelemahan masing-masing.

Model pembelajaran terpadu yang digunakan dalam penelitian ini ada dua jenis, yaitu model nested, model webbed. Pembelajaran terpadu model nested (tersarang) merupakan pengintegrasian kurikulum di dalam satu disiplin ilmu yang secara khusus meletakkan fokus pengintegrasian pada sejumlah keterampilan belajar yang ingin dilatihkan oleh seorang guru kepada siswanya dalam suatu unit pembelajaran untuk ketercapaian materi pelajaran (content). Langkah-langkah model pembelajaran terpadu tipe nested (tersarang) mengikuti tahap-tahap yang dilalui dalam setiap pembelajaran terpadu yang meliputi tiga tahap yaitu tahap perencanaan, tahap pelaksanaan, dan tahap evaluasi. Dalam model nested ini, beberapa keterampilan dapat dipadukan sekaligus dalam suatu pembelajaran di dalam satu mata pelajaran. Akan tetapi, 
ketika tanpa perencanaan yang matang memadukan beberapa keterampilan yang menjadi target dalam suatu pembelajaran akan berdampak pada siswa.

Model pembelajaran terpadu tipe Webbed merupakan pembelajaran terpadu yang menggunakan pendekatan tematik yang dimulai dengan menentukan suatu tema tertentu, tema dapat diperoleh dari negosiasi antara guru dan siswa. Tematema ini nantinya akan dikembangkan lagi dengan memperhatikan keterkaitannya dengan bidang-bidang studi. Dalam memilih tema-tema akan memotivasi siswa untuk belajar dan model webbed lebih mudah dilakukan oleh guru yang belum berpengalaman. Pemilihan tema yang menarik akan memotivasi siswa untuk menerima pelajaran di kelas dengan baik.

Antara masing-masing model pembelajaran yaitu model nested dan model webbed mempunyai kelebihan masing-masing. Berdasarkan hasil penelitian, terlihat bahwa model-model pembelajaran terpadu, seperti model nested dan model webbed dapat memberikan pengaruh kefektifan yang tidak berbeda terhadap hasil belajar siswa, karena setiap model pembelajaran terpadu mempunyai karakter dan ciri khas tersendiri. Model nested dan model webbed terbukti sama-sama efektif dalam meningkatkan hasil belajar siswa.

\section{SIMPULAN}

Hasil penelitian menunjukkan bahwa ratarata hasil belajar dengan model nested dan model webbed dengan nilai t sebesar 0,314 $>$ 0,05 menunjukkan tidak ada perbedaan yang signifikan antara hasil belajar IPS menggunakan model nested dan model webbed. Artinya bahwa hasil belajar IPS dengan menggunakan model nested dan model webbed sama-sama efektif. Dengan demikian hasil belajar dengan model nested dan model webbed tidak berbeda secara signifikan. Hal ini karena model webbed dan model nested merupakan model pembelajaran terpadu yang mempunyai keunggulan.

Untuk meningkatkan hasil belajar IPS akan lebih baik jika menggunakan model-model pembelajaran terpadu. Model pembelajaran terpadu yang terdiri dari 10 model, diantaranya yang diterapkan dalam penelitian ini adalah model nested dan model webbed karena setelah eksperimen diketahui bahwa rerata hasil belajar yang menggunakan model nested dan model webbed jauh lebih tinggi daripada rerata hasil belajar yang menggunakan model konvensional.

Kelengkapan lain seperti bahan ajar, alat dan bahan serta rencana 
pembelajaran menjadi faktor untuk mengembangkan pengetahuan dengan lebih baik lagi karena tanpa persiapan dan kreativitas dari guru maka pelaksanaan pembelajaran terpadu di kelas tidak akan tercapai secara maksimal. Pengembangan pembelajaran model terpadu khususnya model nested dan model webbed lebih efektif daripada model pembelajaran konvensional.

\section{UCAPAN TERIMA KASIH}

Penulis mengucapkan terima kasih kepada civitas akademik di SMP N 2 Depok dan SMP N 3 Depok yang telah membantu proses penelitian. Selanjutnya kami ucapkan terima kasih kepada redaksi yang telah mempublikasikan artikel hasil penelitian ini sehingga penelitian ini dapat dibaca oleh berbagai kalangan. Hasil penelitian ini masih dapat dikembangkan ke dalam bentuk penelitian lain sehingga kami berharap penelitian ini dapat dijadikan sebagai referensi terhadap penelitian selanjutnya. Semoga hasil penelitian ini bermanfaat bagi perkembangan ilmu pengetahuan.

\section{DAFTAR PUSTAKA}

Arikunto, S. 2006. Dasar-dasar evaluasi pendidikan. Jakarta: Bumi Aksara.

Fogarty, R. 1991. The mindfull schools: how to integrate the curricula. Palatine,
Illinois: IRI/Skylight Publishing. Inc.

Hamalik, 0. 2005. Perencanaan pengajaran berdasarkan pendekatan sistem. Jakarta: PT BumiAksara.

Mudyahardjo, R. 2009. Pengantar pendidikan sebuah studi awal tentang dasar-dasar pendidikan pada umumnya dan pendidikan di indonesia. Jakarta: Rajawali Pers.

Sukmadinata, N.S. 2009. Metode Penelitian Pendidikan. Bandung: PT Remaja Rosdakarya.

Widoyoko, E.P. 2009. Evaluasi program pembelajaran. Yogyakarta: 